\title{
The role of superoxide anions in the development of distant
}

\section{tumour recurrence}

\author{
M ten Kate', JBC van der Wal', W Sluiter ${ }^{2}$, LJ Hofland ${ }^{3}$, J Jeekel', P Sonneveld ${ }^{4}$ and CHJ van Eijck, \\ 'Department of Surgery, Erasmus MC, Dr Molewaterplein 40, 3015 GD Rotterdam, The Netherlands; '2Department of Biochemistry, Erasmus MC, \\ Rotterdam, The Netherlands; ${ }^{3}$ Department of Internal Medicine, Erasmus MC, Rotterdam, The Netherlands and ${ }^{4}$ Department of Hematology, Erasmus \\ MC, Rotterdam, The Netherlands
}

\begin{abstract}
We hypothesise that reactive oxygen species (ROS) released from activated polymorphonuclear leucocytes during surgery play a crucial role in enhanced tumour recurrence seen after surgery. Therefore, the effect of ROS on adhesion of tumour cells to microvascular endothelium in a reproducible human in vitro model was studied. Preincubation of microvascular endothelial cells with the superoxide anion producing xanthine-xanthine oxidase complex significantly increased adhesion of the human colon carcinoma cells HT29 (I67\% vs control, $P<0.0$ I), Caco2 (I64\% vs control, $P<0.0$ I) and of the pancreas carcinoma cells PanCl (I80\% vs control, $P<0.01$ ). Addition of the antioxidant enzymes superoxide dismutase or catalase significantly decreased tumour cell adhesion $(P<0.01)$. Exposure of endothelial cells to superoxide anions increased the apoptotic rate to 7.9 times the normal rate. Additionally, exposure increased expression of the endothelial adhesion molecules E-Selectin, ICAM- I, and VCAM-I of maximally I 70\% vs control $(P<0.0 \mathrm{I})$. In conclusion, this study shows that superoxide anions promote the adherence of tumour cells to the microvasculature by inducing endothelial apoptosis that subsequently induces the expression of various adhesion molecules for tumour cells. This indicates that by tackling the production of ROS preventing tumour recurrence at distant sites might be feasible. British Journal of Cancer (2006) 95, |497- 1503. doi:I0.I038/sj.bjc.6603436 www.bjcancer.com Published online 7 November 2006

(c) 2006 Cancer Research UK
\end{abstract}

Keywords: surgical trauma; ROS; tumour cell; microvascular endothelium; adhesion

Despite the introduction of new treatment modalities for gastrointestinal malignancies during the last decades surgery remains the principal therapy for most gastrointestinal malignancies, although the recurrence rates after intentionally curative surgery are high (August et al, 1984; Midgley and Kerr, 1999; Wayne et al, 2002; Link et al, 2005).

Operative trauma in itself may favour development of tumour recurrence. This relation between abdominal surgery and locoregional tumour recurrence was investigated in previous in vivo and in vitro experiments. These studies illustrated that surgical trauma enhanced locoregional tumour recurrence and that this phenomenon involved a dose-response relation, that is, severe trauma was associated with a higher locoregional tumour recurrence rate compared to mild trauma (Busch et al, 1993; Bouvy et al, 1997; van den Tol et al, 1998; van Rossen et al, 1999, 2000). Further experiments demonstrated that abdominal surgical trauma provoked a local inflammatory reaction with influx of mainly polymorphonuclear cells (PMN). These activated PMN produced reactive oxygen species (ROS) which are found to play an important role in the observed enhanced locoregional tumour

*Correspondence: Dr CHJ van Eijck;

E-mail: c.vaneijck@erasmusmc.nl

Received II August 2006; revised 20 September 2006; accepted 25 September 2006; published online 7 November 2006 recurrence in which binding of the tumour cells to the mesothelium is an essential step (van Rossen et al, 1999, 2000).

The inflammatory reaction caused by abdominal surgical trauma is not confined to the abdominal cavity, but spreads out systemically (Weese et al, 1986; Baigrie et al, 1992; Yokota et al, 1995; Aosasa et al, 2000; Shiromizu et al, 2000; Pross et al, 2002; Ure et al, 2002). So is it found that during and shortly after major surgery, the peripheral blood level of elastase, which is an indicator of PMN activity, is elevated (Oka et al, 1994; Noshima et al, 1997; Varga et al, 1997; Hildebrandt et al, 2003; Miyaoka et al, 2005). Furthermore, major abdominal surgery results in an elevated PMN concentration at distant sites, for example in the lung leading to a distant inflammatory reaction (Fosse et al, 1987). Therefore, surgical trauma may not only promote local tumour recurrence, but also tumour recurrence at distant sites.

Cancer dissemination is frequently accomplished via the blood stream. Although many circulating tumour cells fail to survive this phase of the metastatic cascade, the establishment of metastases depends upon the arrest of surviving cells and their exit from the circulation, which involves adhering to and crossing the barriers imposed by the microvascular endothelium and extracellular matrix (Weiss, 1985; Fosse et al, 1987).

Based on the previous studies that demonstrate an important role for ROS in locoregional tumour recurrence after surgical trauma, combined with the systemic inflammatory process after surgical trauma, we hypothesise that ROS enhance distant tumour recurrence by increased tumour cell adhesion to the endothelium. 
In this study therefore, we investigate the influence of ROS on tumour cell-endothelial cell interactions. The underlying mechanism of the enhanced adhesion by PMN-derived ROS will be further elucidated. Two tumour cell types were used, namely colon and pancreas carcinoma cells to assess the effect of superoxide anions on tumour cell-endothelial cell interactions with focus on the expression of a variety of cellular adhesion molecules and the occurrence of apoptosis of both the tumour and microvascular endothelial cells (MEC).

\section{MATERIALS AND METHODS}

\section{Cells}

Human MECs of the lung were purchased from Cambrex (Verviers, Belgium) at passage 4 and maintained in EGM-2-MV Bullet kit according to the manufacturer's instructions at $37^{\circ} \mathrm{C}$, $95 \%$ relative humidity and $5 \% \mathrm{CO}_{2}$. Confluent monolayers were passaged by $0.025 \%$ trypsin $/ 0.01 \%$ ethylenediaminetetraacetic acid (EDTA) and cells were used up to passage 8.

The human colon carcinoma cell lines HT29 and Caco2 and the human pancreas carcinoma cell line PanC1 were grown in EGM-2MV Bullet kit as well in order to create similar conditions and maintained by serial passage after trypsinisation using $0.05 \%$ trypsin $/ 0.02 \%$ EDTA (Gibco, Breda, The Netherlands).

Before the adhesion assay, tumour cells were trypsinised and maintained in suspension for $2 \mathrm{~h}$ to regenerate cell-surface proteins.

\section{Reactive oxygen species and scavengers}

In this study, the xanthine $(\mathrm{X})$-xanthine oxidase (XO) complex was used in a concentration of $100 \mu \mathrm{M}$ and $30 \mathrm{mU} \mathrm{ml}^{-1}$, respectively (Sigma-Aldrich, Zwijndrecht, the Netherlands), to produce superoxide anions.

Superoxide anions were inactivated by the addition of $400 \mathrm{U} \mathrm{ml}^{-1}$ superoxide dismutase (SOD) (Roche Applied Science, Almere, The Netherlands) that converts superoxide anions into molecular oxygen and hydrogen peroxide. As hydrogen peroxide may itself affect tumour cell adhesion, $400 \mathrm{U} \mathrm{ml}^{-1}$ catalase (SigmaAldrich, Zwijndrecht, The Netherlands) was added to the in vitro model alone or in combination with SOD to decompose any hydrogen peroxide.

\section{Ferricytochrome $c$ reduction assay}

To assess production of superoxide anions generated by the combination of $\mathrm{X}$ and $\mathrm{XO}$ in our model we used the ferricytochrome $c$ reduction assay (Markert et al, 1984). This assay was performed in phenol red-free and phosphate-buffered Hank's Balanced Salt Solution (Invitrogen, Breda, the Netherlands) with $5 \%$ foetal calf serum, as phenol red and $\mathrm{pH}$ changes effect the assay. After addition of $75 \mu \mathrm{M}$ cytochrome $c$ (Roche Applied Science, Almere, The Netherlands) the change in absorbance at 550 and $540 \mathrm{~nm}$ (reference) was continuously recorded by the thermostatted Versamax microplate reader (Molecular Devices) for $125 \mathrm{~min}$ at $37^{\circ} \mathrm{C}$.

\section{Adhesion assay}

To quantify tumour cell adhesion to MEC, a standardised cell adhesion assay was developed as described before (Catterall et al, 1994). Briefly, endothelial monolayers were established in 96-well microtitre plates (Perkin Elmer, Groningen, The Netherlands). To do this, confluent cells were trypsinised and $2 \times 10^{4}$ endothelial cells were added to each well.

The plates were incubated at $37^{\circ} \mathrm{C}, 95 \%$ relative humidity, $5 \%$ $\mathrm{CO}_{2}$, and medium was daily replaced by fresh medium. Micro- vascular endothelial cells reached confluence in 3-4 days as determined by light microscopy.

To determine the effect of ROS on tumour cell adhesion, endothelial monolayers were preincubated with varying doses of $\mathrm{X}$ and $\mathrm{XO}$, during varying times. Untreated monolayers served as controls. Tumour cells were preincubated or not with the $\mathrm{X}-\mathrm{XO}$ complex for $12 \mathrm{~h}$ before the adhesion assay.

Appropriate SOD and/or catalase were added to the model system to assess ROS specificity of the effects.

To quantify tumour cell adhesion, tumour cells $\left(1 \times 10^{6}\right.$ cells $\mathrm{ml}^{-1}$ ) were labelled with calcein-AM (Molecular Probes, Leiden, The Netherlands) and $3 \times 10^{4}$ cells per well were added. Plates were centrifuged for $1 \mathrm{~min}$ at $80 \times g$ and incubated at $37^{\circ} \mathrm{C}$ for $1 \mathrm{~h}$. After this, the wells were washed twice with medium. The remaining fluorescence per well was measured on a Perkin Elmer plate reader using a wavelength of $485 \mathrm{~nm}$ for excitation and $530 \mathrm{~nm}$ for emission respectively.

\section{Enzyme immunoassay (EIA)}

Endothelial and tumour cells were grown to confluence as described for the adhesion assays in 96-well flat-bottomed microtiter plates (Becton \& Dickinson, Erembodegem, Belgium). Cells were preincubated with either cell culture medium alone or combined with X and/or XO. Next, the cells were washed with phosphate-buffered saline (room temperature, $\mathrm{pH}$ 7.4) and fixed in ethanol/methanol for $45 \mathrm{~min}$ and washed again. Subsequently, nonspecific binding sites were blocked by incubating the wells for 10 min with $1 \%$ goat serum (Sigma-Aldrich, Zwijndrecht, The Netherlands). Mouse monoclonal antibody to E-Selectin, intracellular adhesion molecule-1 (ICAM-1), or vascular cellular adhesion molecule-1 (VCAM-1) (ITK, Uithoorn, The Netherlands) in a dilution of $1: 500$ was added for $1 \mathrm{~h}$, followed by the addition of biotinylated goat anti-mouse antibody (Sigma-Aldrich, Zwijndrecht, the Netherlands) in a dilution of $1: 250$. Increased sensitivity was obtained using the ExtrAvidin-Peroxidase system (Sigma-Aldrich, Zwijndrecht, the Netherlands). After washing away any free peroxidase, a substrate solution containing $2,2^{\prime}$ azino-bis(3-ethylbenzothiazoline-6-sulfonic acid) diammonium salt in $0.05 \mathrm{M}$ citrate-phosphate buffer with urea hydrogen peroxide buffer with urea hydrogen peroxide was added. Incubation of endothelial cells without the primary antibody served as a negative control. As a positive control, the ExtrAvidin-Peroxidase system was added followed by substrate development without washing away the peroxidase. After $40 \mathrm{~min}$ the reaction was stopped with sodium fluoride and photometrical evaluation was performed with a computer-controlled ELISA reader at $\lambda=405 \mathrm{~nm}$.

\section{Apoptosis}

To assess whether superoxide anions caused apoptosis in MEC a cell-death detection ELISA ${ }^{\text {plus }}$ kit (Roche Applied Science, Almere, The Netherlands) was used for the detection of cytoplasmic histone-associated DNA fragments. In short, endothelial cells were grown to confluence as described for the adhesion assays in 96-well flat-bottomed microtitre plates. The cells were preincubated with $\mathrm{X}$ and/or XO for $12 \mathrm{~h}$ and then lysated, whereafter $20 \mu \mathrm{l}$ of the lysate was transferred into Streptavidincoated microplate wells. Eighty microlitre of immunoreagent containing biotinylated anti-histone and peroxidase-labelled antiDNA antibodies was added into the wells followed by incubation on a plate shaker under gently shaking (300 r.p.m.) for $2 \mathrm{~h}$ at $15-$ $25^{\circ} \mathrm{C}$. Then the wells were washed thoroughly with incubation buffer and $100 \mu$ l of 2,2'-azino-bis-(3-ethylbenzthiazoline-6-sulfonic acid) substrate was added. Plates were incubated for $15 \mathrm{~min}$ on a plate shaker at 250 r.p.m. where after photometric analysis at $405 \mathrm{~nm}$ was performed. 


\section{Proliferation assay}

To establish whether preincubation of MEC monolayers with superoxide anions was of influence on MEC cell number, the DNA content was determined using the bisbenzimide fluorescent dye (Roche Applied Science, Almere, The Netherlands) as previously described by Hofland et al (1990). Therefore, $2 \times 10^{4}$ endothelial cells $\mathrm{ml}^{-1}$ were plated in 24-wells plates and after 1 day X-XO was added. At days $0,1,2$, and 3 after the addition of $\mathrm{X}$-XO wells were washed and plates were stored at $-20^{\circ} \mathrm{C}$ until analysis.

\section{Statistical analysis}

All data were evaluated using analysis of variance to determine overall differences between groups. The Dunnett post-test was carried out to compare between groups. $P \leqslant 0.05$ was considered to be statistically significant. Experiments $(n=6)$ were performed at least twice.

\section{RESULTS}

\section{Evaluation of the model}

Labelling tumour cells with calcein-AM did not decrease their viability ( $>95 \%$ using trypan blue). Dilution series of labelled tumour cells on endothelial monolayers showed a linear correlation $\left(r^{2}>0.99\right)$ between cell number and the level of fluorescence (Figure 1). Thus, by using such standard curves it became possible to estimate the number of adherent tumour cells in the experimental wells from the fluorescence intensity.

In our model, ferricytochrome $c$ in the wells with $\mathrm{X}-\mathrm{XO}$ was reduced at a rate of $0.32 \mathrm{nmol} \mathrm{ml}^{-1} \mathrm{~min}^{-1}$ as can be calculated from the results presented in Figure 2 using a molecular extinction coefficient of ferricytochrome $c$ of $13.125 \mathrm{M}^{-1}$ for a light path of $0.625 \mathrm{~cm}$ in the microtitre plate. The addition of SOD prevented the reduction of ferricytochrome $c$ completely, indicating that the $\mathrm{X}-\mathrm{XO}$ system indeed mainly generated superoxide and that $400 \mathrm{U} \mathrm{ml}^{-1}$ SOD is sufficient in this model to dismutate the formed superoxide anions. Interestingly, in the absence of $\mathrm{X}-\mathrm{XO}$ still generated superoxide, but at a lower rate (Figure 2). In the assay with XO only in the absence of foetal calf serum, we found no superoxide production (data not shown), whereas in the presence of foetal calf serum, but without the addition of XO and extra X, MEC also were found to produce some superoxide (Figure 2). This made it likely that the foetal calf serum of the medium contained the necessary substrate $\mathrm{X}$, and that MEC contain some endogenous $\mathrm{XO}$ (Figure 2).

\section{Adhesion to microvascular endothelial cells}

Basal adhesion, that is, adhesion to non-preincubated MEC, was between 20 and $30 \%$ of added cells for HT29 and Caco2. For PanC1, basal adhesion was between 10 and $20 \%$.

Preincubation of MEC with the $\mathrm{X}-\mathrm{XO}$ complex enhanced tumour cell adhesion (Figure 3). For PanC1, this enhancement occurred after $12 \mathrm{~h}$ preincubation and was increasing with longer preincubation times reaching a maximum of $180 \% v s$ control (untreated MEC) after $24 \mathrm{~h}$ of preincubation $(P<0.01)$. Comparable results were found for $\mathrm{Caco} 2$ after $\mathrm{X}-\mathrm{XO}$ preincubation of MEC with a tumour cell adhesion of $164 \%$ compared to basal adhesion $(P<0.01)$. Maximal adhesion for HT29 occurred already after $12 \mathrm{~h}$ preincubation of MEC with $\mathrm{X}-\mathrm{XO}$ and was $167 \%$ vs control $(P<0.01)$.

Preincubation with $\mathrm{X}$ alone did not influence tumour cell adhesion for all three cell lines (Figure 4). However, preincubation with XO alone did enhance the adhesion of HT29 to $172 \%$, of Caco 2 to $170 \%$, and of PanC1 to $128 \%$ vs control (all $P<0.01$ ) (Figure 4). This was not surprising, as $\mathrm{XO}$ in medium alone did produce superoxide anions (Figure 2), probably because foetal calf serum in the medium contains $\mathrm{X}$, acting as a substrate for $\mathrm{XO}$.

Preincubation of HT29, Caco2, and PanC1 with the X-XO complex for $12 \mathrm{~h}$ did not enhance their adhesion to untreated or pretreated MEC statistically significantly (Figure 5; only data for HT29 are shown).

To verify if superoxide is the relevant ROS causing the enhanced adhesion we evaluated the effects of SOD in this model (Figure 4). Addition of SOD did decrease the enhanced adhesion of Caco2 to $\mathrm{X}$-XO-treated MEC to nearly basal levels, from 158 to $116 \%$ $(P<0.01)$. Comparable results were observed for HT29. SOD also decreased adhesion of PanC1 to X-XO-treated MEC, from 299 to $213 \%(P<0.05)$. As superoxide anions spontaneously dismutate into the stronger ROS hydrogen peroxide that may affect MEC on its turn, we studied the effect of catalase next. The results showed that catalase inhibited the enhanced tumour cell adhesion
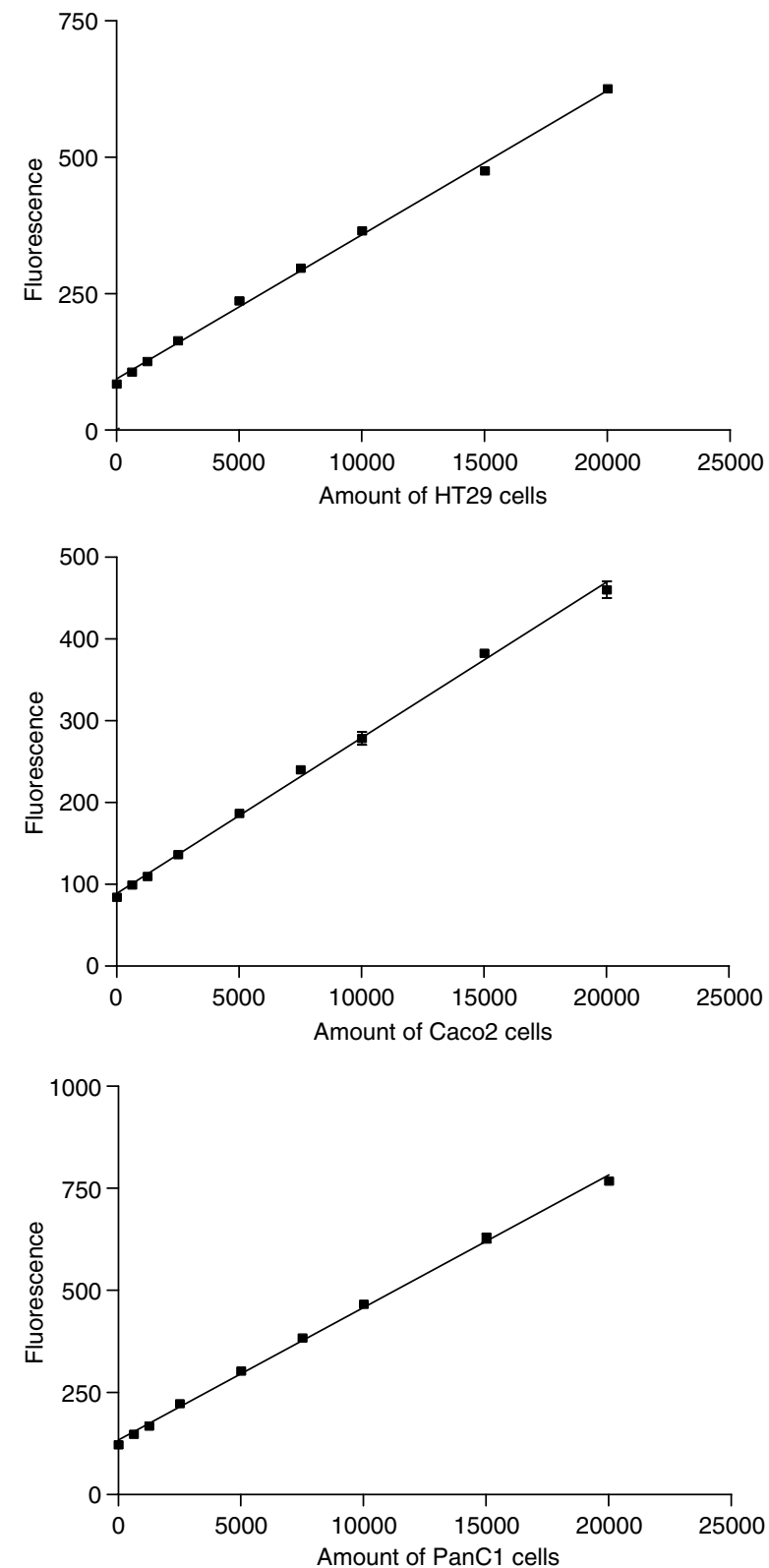

Figure I Calibration curves showing the fluorescence measurements (OD 485-530 nm) of calcein-AM-labelled tumour cells in order to quantify the amount of tumour cells. Data represent mean \pm s.e.m. of duplicate wells. 
after X-XO preincubation effectively as well, that is, for HT29 adhesion decreased from 167 to $141 \%(P<0.05)$, for Caco2 from 158 to $113 \%(P<0.01)$, and for PanC1 from 299 to $163 \%(P<0.01)$. In combination both antioxidant enzymes did not gave an

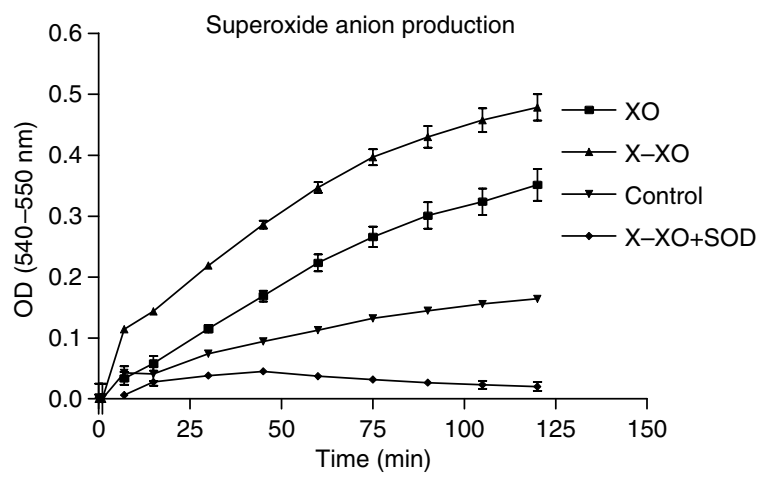

Figure 2 Validation of superoxide anion production by the ferricytochrome $c$ reduction assay. Xanthine-xanthine oxidase was added to the wells with or without $400 \mathrm{Uml}^{-1}$ SOD immediately followed by the addition of $75 \mu \mathrm{M}$ cytochrome c. Continuous measurements at 550 $540 \mathrm{~nm}$ were carried out for $125 \mathrm{~min}$. Data represent mean absorbance values (OD $540-550 \mathrm{~nm}$ ) \pm s.e.m. of quadriplate wells.

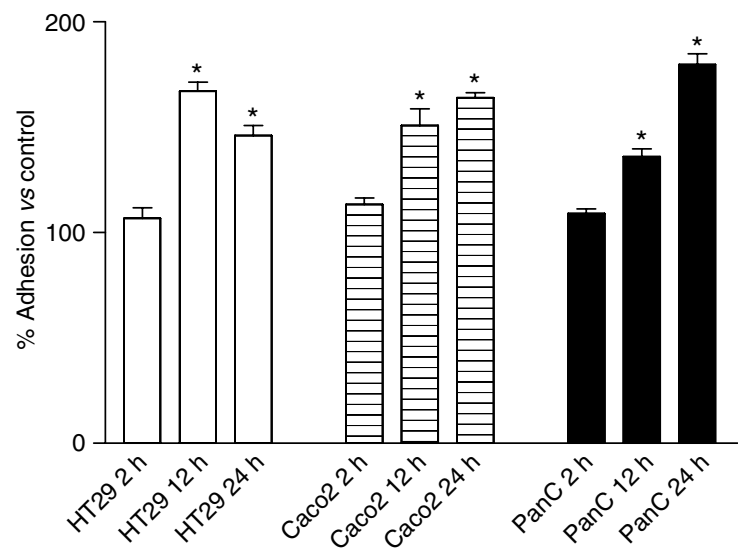

Figure 3 Tumour cell adhesion to MEC after preincubation of MEC with $X-X O$ at varying time intervals. Means $(n=6 ; \%$ vs control) \pm s.e.m. are shown. $* P<0.01$ vs control. additional effect. The addition of SOD or catalase to untreated MEC did not decrease basal adhesion alone (Figure 4), indicating that the low level of superoxide production of MEC in culture medium was insufficient to act as an autocrine stimulus (Figure 2).

\section{Mechanism of adhesion}

To study if preincubation with $\mathrm{X}$ - $\mathrm{XO}$ influences the number of MEC we determined the course in the amount of DNA during an observation period of 3 days. The results showed a significant decline in the amount of DNA, not until 2 days of incubation with $\mathrm{X}-\mathrm{XO}$ (Figure 6A). During the first $24 \mathrm{~h}$ of culture in presence or absence of X-XO however, the number of MEC as reflected by the amount of DNA did not change significantly. Photographs of the endothelial monolayers with or without preincubation with $\mathrm{X}-\mathrm{XO}$ for $12 \mathrm{~h}$ also show that the number of endothelial cells is comparable (Figure 6B). On the other hand, preincubation with $\mathrm{X}-\mathrm{XO}$ did lead to an increased apoptosis rate of 7.9 times the normal apoptosis rate $(P<0.01)$, whereas XO only stimulated the apoptosis rate 3.7 -fold $(P<0.01)$ (Figure 7$)$.

It was previously shown (Chirivi et al, 1994; Giavazzi, 1996; Orr et al, 2000; ten Kate et al, 2004) that the adhesion molecules E-Selectin, ICAM-1, and VCAM-1 on MEC and the ligands lymphocyte function-associated antigen-1, very late activation antigen-4 and CD44 on tumour cells play an important role in tumour cell adhesion to MEC and that the expression of these
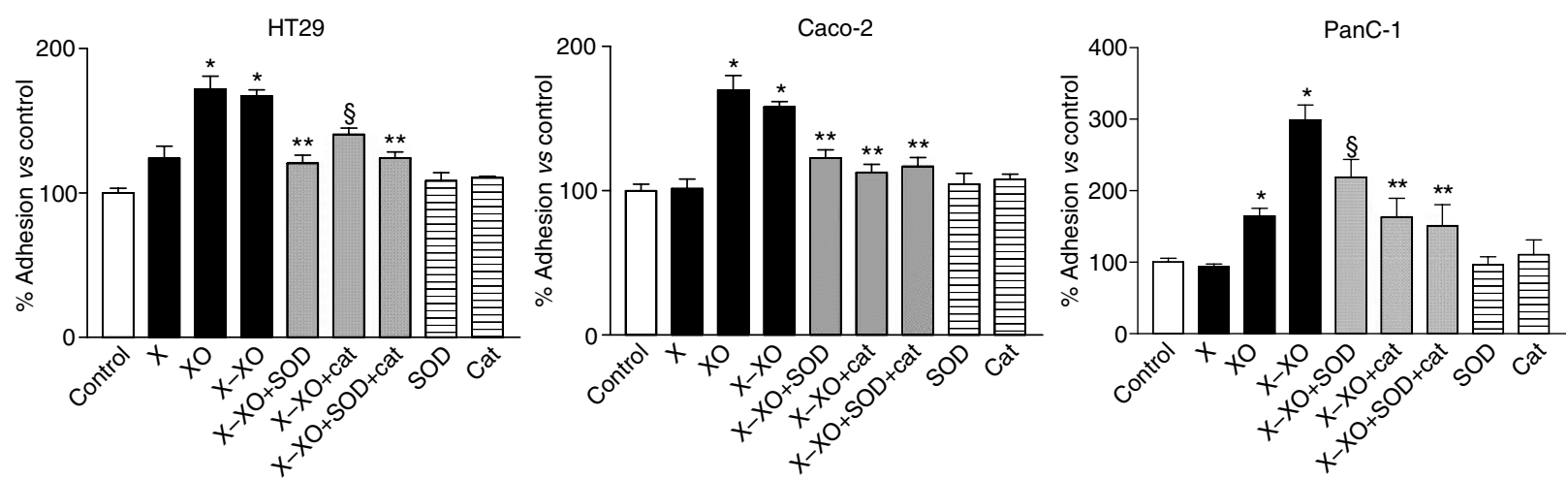

Figure 4 Adhesion of HT29 (A), Caco2 (B), and $\mathrm{PanCl}(\mathbf{C})$ after $12 \mathrm{~h}$ preincubation of MEC with $\mathrm{X}, \mathrm{XO}$, and $\mathrm{X}$ - $\mathrm{XO}$. The antioxidant enzymes SOD, catalase (cat) and the combination of both were added during the preincubation. Measurement of adhesion to an empty well (plastic) was determined as a negative control. Means $(n=6 ; \%$ vs control) \pm s.e.m. are shown. $* P<0.0$ I vs control; $* * P<0.0$ I vs $X-X O$; $\$ P<0.05$ vs $X-X O$. 


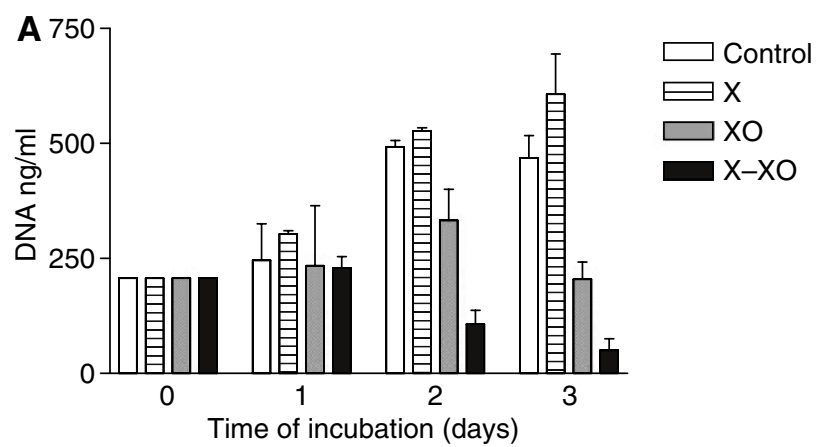

B

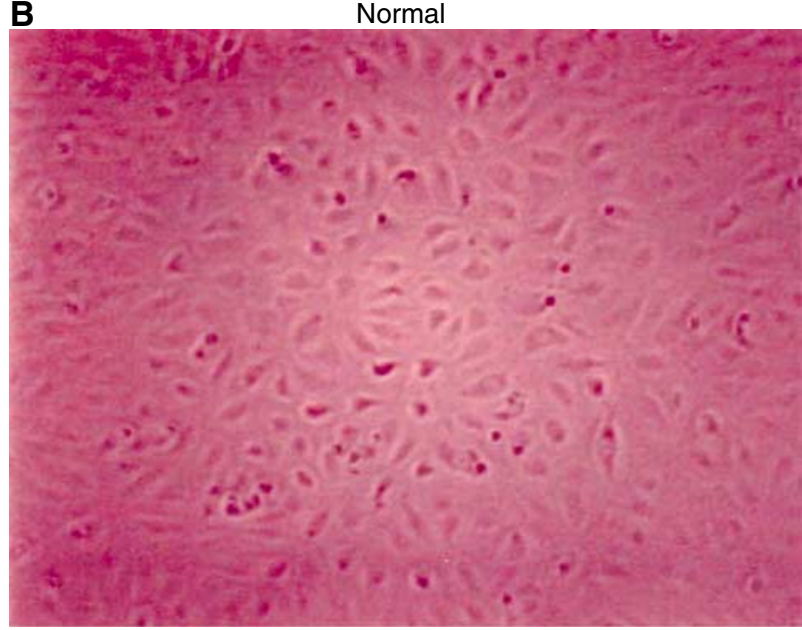

Preincubation with IL-1 $\beta$

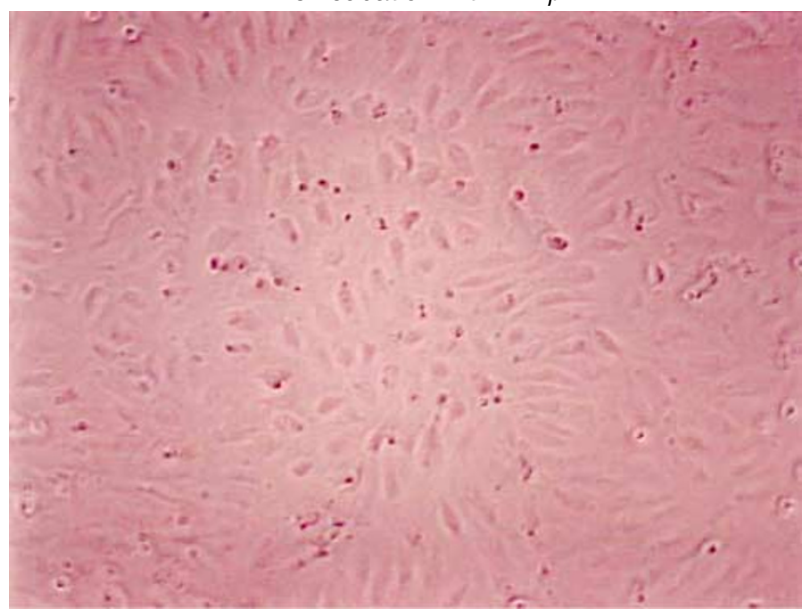

Figure 6 (A) MEC proliferation assay. DNA in $\mathrm{ng} \mathrm{ml}^{-1}$ of MEC after 0 , I, 2, and 3 day(s) incubation with $X, X O$, and $X-X O$. Bars represent means $(n=4)$. (B) Photographs of MEC monolayers: in medium (normal) and in medium preincubated with $\mathrm{X}-\mathrm{XO}$ for $12 \mathrm{~h}$. Comparable number of cells are seen.

molecules can be induced by apoptosis (Hebert et al, 1998b; Chandra et al, 2003a).

In this model we found that nonstimulated MEC and tumour cells did express E-Selectin, ICAM-1, and VCAM-1 (Figures 8 and 9). After $8 \mathrm{~h}$ of preincubation with $\mathrm{X}-\mathrm{XO}$, enhanced E-Selectin expression on MEC was observed with a peak expression after $12 \mathrm{~h}$ of 1.66 times the expression on nonstimulated MEC $(P<0.01)$. Increased ICAM-1 and VCAM-1 expression on MEC was observed later, namely after $12 \mathrm{~h}$ preincubation. Although ICAM-1 expression then increased still further to a maximum of $170 \% v s$ control

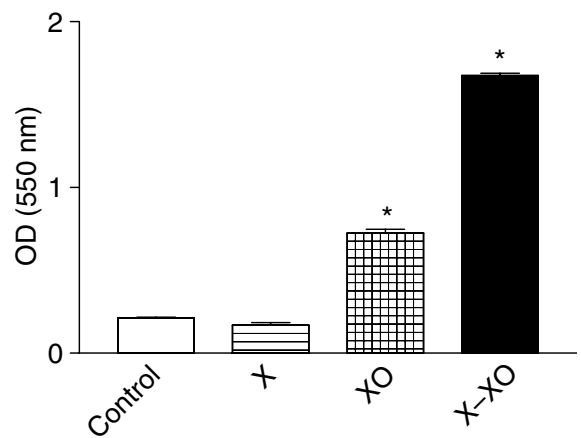

Figure 7 Measurement of apoptosis by ELISA in MEC after preincubation with $\mathrm{X}, \mathrm{XO}$, and $\mathrm{X}-\mathrm{XO}$ for $12 \mathrm{~h}$. Data represent mean absorbance values (OD $550 \mathrm{~nm}$ ) \pm s.d. of triplate wells. $* P<0.0$ I vs control.

$(P<0.01)$, VCAM-1 expression declined after its peak expression of $149 \% v s$ control at $12 \mathrm{~h}$ of preincubation (Figure 6). None of the adhesion molecules under study showed enhanced expression on HT29 (Figure 9), Caco2, and PanC1 by X-XO preincubation (data not shown).

\section{DISCUSSION}

ROS are known to play an important role in locoregional tumour recurrence after surgical trauma (van Rossen et al, 1999, 2000). In preliminary in vivo studies, we were able to detect a significant increase of ROS in peritoneal lavage fluid as well as in plasma after surgery, proving that indeed surgery induces not only a local enhancement of ROS, but also systemically (data not shown). So the inflammatory response after surgical trauma does not confine locally, but spreads out systemically and therefore it is interesting to investigate the role of ROS in the development of distant metastases after surgery.

Therefore, the X-XO complex was used to generate superoxide anions and in this way the influence of superoxide anions on tumour cell-endothelial cell interactions was studied. Exposure of microvascular endothelium to superoxide anions gave a substantial enhancement in tumour cell adhesion to the exposed endothelium comparable to the results found with PMN exposure, whereas exposure of tumour cells to superoxide anions had no effect on their adhesion to untreated endothelial cells.

We found that exposure of the MECs to superoxide anions led to an upregulation of the adhesion molecules E-Selectin, ICAM-1, and VCAM-1 on these cells. Enhancement of adhesion molecules on endothelial cells by exposure to ROS was also found by Bradley et al (1993) and Lo et al (1993). Both found significant increased ICAM-1 expression after preincubation with the ROS, although a relation with tumour adhesion was not investigated. Terada et al (1997) did not found an upregulation of ICAM-1 on the endothelium after a short preincubation period of $30 \mathrm{~min}$ with XO. This period of time is too short for completing synthesis of functional adhesion molecules, which is in accordance to our observation that a continuous exposure of the endothelium to ROS lasting minimally $12 \mathrm{~h}$ is necessary before endothelial cells show any increased expression of cellular adhesion molecules.

Exposure of the endothelium to superoxide anions resulted in a major increase of apoptosis. Apoptosis finally will result in cell death leading to loss of binding sites on the endothelium, but exposure of the underlying extracellular matrix as a substrate for binding sites for circulating tumour cells. However, it does not seem very likely that binding sites on the extracellular matrix contributed to the findings of the present study, because the preincubation of the endothelial cells lasted only $12 \mathrm{~h}$ during which the number of endothelial cells did not decrease. 

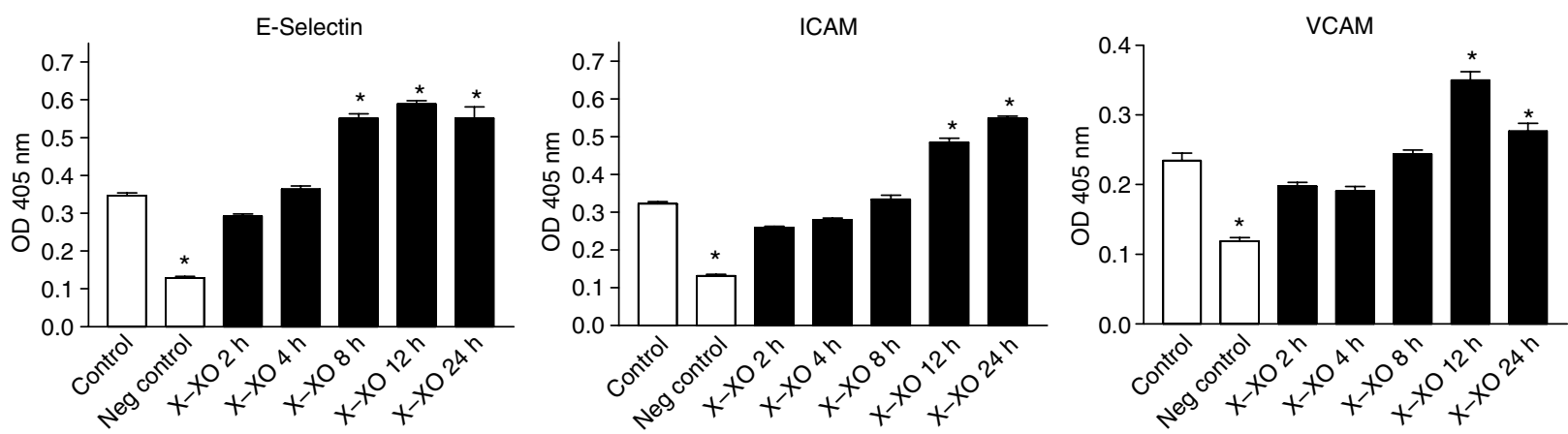

Figure 8 Adhesion molecule expression on MEC. After 2-24h preincubation with $\mathrm{X}-\mathrm{XO}$, EIA with anti-E-Selectin, anti-ICAM,- and anti-VCAMantibodies was performed. Bars represent the mean absorbance values (OD $405 \mathrm{~nm}$ ) \pm s.d. of quadriplate wells. $* P<0.01$ vs control.

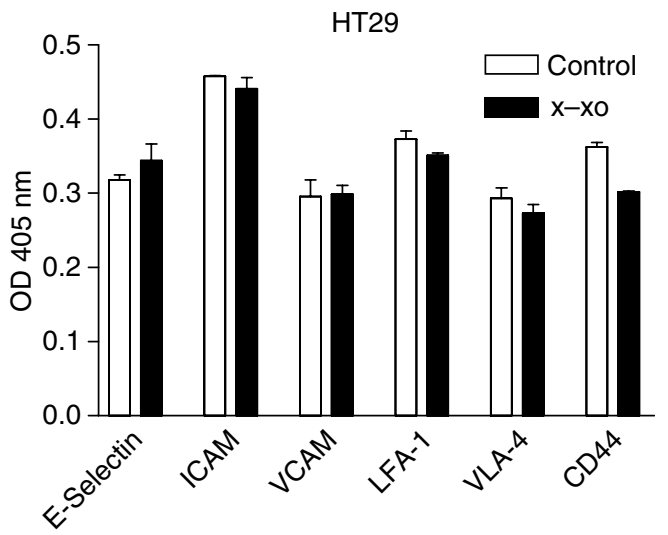

Figure 9 Adhesion molecule expression on HT29 colon carcinoma cells. After $12 \mathrm{~h}$ preincubation with $\mathrm{X}-\mathrm{XO}$, EIA was performed. Bars represent the mean absorbance values (OD $405 \mathrm{~nm}) \pm$ s.d. of quadriplate wells.

The fact that endothelial cells undergoing apoptosis release interleukin $-1 \beta$ (IL-1 $\beta$ ) that via a paracrine loop in turn stimulates the expression of adhesion molecules on the endothelial cells (Hebert et al, 1998a; Chandra et al, 2003b) suggests that the following sequence of events for the recurrence of tumour cells at distant sites occur. Surgical trauma during the excision of a (primary) tumour leads to the activation of PMN. At distant sites these phagocytes by their massive production of ROS induce apoptosis of microvascular endothelium. Subsequently, by the (local) release of IL- $1 \beta$ the endothelial cells stimulate the expression of at least three major cellular adhesion molecules on their own cell membrane to which circulating tumour cells now easily can adhere and next form a metastasis.

The addition of SOD and/or catalase to ROS-exposed MEC decreased the enhanced tumour cell adhesion significantly. As both antioxidant enzymes decreased the adhesion to similar levels this means that not only superoxide anions, but also hydrogen peroxide are equally involved in this phenomenon. This indicates that in fact a third kind of ROS, namely the highly reactive hydroxyl radical, is the actual reactant. To generate hydroxyl radicals both superoxide and hydrogen peroxide are needed in the so-called transition metal catalysed Haber-Weiss reaction, and thus depleting one or the other ROS completely prevents the generation of the hydroxyl radical. Of note is that the addition of either SOD or catalase did not decrease the adhesion to basal levels. Incomplete scavenging of ROS by the antioxidant enzymes cannot account for that, because we showed here that adding SOD to the X-XO complex completely inhibited the generation of superoxide. Presumably the local increase in tension of molecular oxygen as a by-product of the inactivation of superoxide and hydrogen peroxide by SOD and catalase, or XO itself may have contributed to the incomplete reduction in the expression of the adhesion molecules.

In conclusion, the results of the present study suggest that ROS as a result of surgical trauma influence tumour recurrence at distant sites by increasing binding sites for tumour cells on the endothelium. This indicates that by tackling the production of ROS preventing tumour recurrence not only locally, but also at distant sites might be feasible.

\section{REFERENCES}

Aosasa S, Ono S, Mochizuki H, Tsujimoto H, Osada S, Takayama E, Seki S, Hiraide $H$ (2000) Activation of monocytes and endothelial cells depends on the severity of surgical stress. World J Surg 24: 10-16

August DA, Ottow RT, Sugarbaker PH (1984) Clinical perspective of human colorectal cancer metastasis. Cancer Metast Rev 3: $303-324$

Baigrie RJ, Lamont PM, Kwiatkowski D, Dallman MJ, Morris PJ (1992) Systemic cytokine response after major surgery. Br J Surg 79: 757-760

Bouvy ND, Marquet RL, Jeekel J, Bonjer HJ (1997) Laparoscopic surgery is associated with less tumour growth stimulation than conventional surgery: an experimental study. Br J Surg 84: 358-361

Bradley JR, Johnson DR, Pober JS (1993) Endothelial activation by hydrogen peroxide. Selective increases of intercellular adhesion molecule-1 and major histocompatibility complex class I. Am J Pathol 142: 1598-1609

Busch OR, Hop WC, Hoynck van Papendrecht MA, Marquet RL, Jeekel J (1993) Blood transfusions and prognosis in colorectal cancer. N Engl J Med 328: $1372-1376$

Catterall JB, Gardner MJ, Jones LM, Thompson GA, Turner GA (1994) A precise, rapid and sensitive in vitro assay to measure the adhesion of ovarian tumour cells to peritoneal mesothelial cells. Cancer Lett 87: 199-203

Chandra D, Ramana KV, Friedrich B, Srivastava S, Bhatnagar A, Srivastava SK (2003b) Role of aldose reductase in TNF-alpha-induced apoptosis of vascular endothelial cells. Chem Biol Interact 143-144: 605-612

Chandra D, Ramana KV, Friedrich B, Srivastava S, Bhatnagar A, Srivastava SK (2003a) Role of aldose reductase in TNF-alpha-induced apoptosis of vascular endothelial cells. Chem Biol Interact 143-144: $605-612$

Chirivi RG, Nicoletti MI, Remuzzi A, Giavazzi R (1994) Cytokines and cell adhesion molecules in tumor-endothelial cell interaction and metastasis. Cell Adhes Commun 2: 219-224

Fosse E, Opdahl H, Sunde S, Aasen AO, Svennevig JL (1987) Granulocytes in bronchial lavage fluid after major vascular surgery. Acta Anaesthesiol Scand 31: 33-37 
Giavazzi R (1996) Cytokine-mediated tumor-endothelial cell interaction in metastasis. Curr Top Microbiol Immunol 213(Part 2): 13-30

Hebert MJ, Gullans SR, Mackenzie HS, Brady HR (1998a) Apoptosis of endothelial cells is associated with paracrine induction of adhesion molecules: evidence for an interleukin-1beta-dependent paracrine loop. Am J Pathol 152: 523-532

Hebert MJ, Gullans SR, Mackenzie HS, Brady HR (1998b) Apoptosis of endothelial cells is associated with paracrine induction of adhesion molecules: evidence for an interleukin-1beta-dependent paracrine loop. Am J Pathol 152: 523-532

Hildebrandt U, Kessler K, Plusczyk T, Pistorius G, Vollmar B, Menger MD (2003) Comparison of surgical stress between laparoscopic and open colonic resections. Surg Endosc 17: 242-246

Hofland LJ, van Koetsveld PM, Lamberts SW (1990) Percoll density gradient centrifugation of rat pituitary tumor cells: a study of functional heterogeneity within and between tumors with respect to growth rates, prolactin production and responsiveness to the somatostatin analog SMS 201-995. Eur J Cancer 26: 37-44

Link KH, Kornmann M, Staib L, Redenbacher M, Kron M, Beger HG (2005) Increase of survival benefit in advanced resectable colon cancer by extent of adjuvant treatment: results of a randomized trial comparing modulation of 5-FU + levamisole with folinic acid or with interferonalpha. Ann Surg 242: 178-187

Lo SK, Janakidevi K, Lai L, Malik AB (1993) Hydrogen peroxide-induced increase in endothelial adhesiveness is dependent on ICAM-1 activation. Am J Physiol 264: L406-L412

Markert M, Andrews PC, Babior BM (1984) Measurement of O2production by human neutrophils. The preparation and assay of NADPH oxidase-containing particles from human neutrophils. Methods Enzymol 105: $358-365$

Midgley R, Kerr D (1999) Colorectal cancer. Lancet 353: 391 - 399

Miyaoka K, Iwase M, Suzuki R, Kondo G, Watanabe H, Ito D, Nagumo M (2005) Clinical evaluation of circulating interleukin-6 and interleukin-10 levels after surgery-induced inflammation. J Surg Res 125: 144-150

Noshima S, Morita N, Kobayashi Y, Hayashi D, Okamura K, Takahashi T, Kobayashi T, Enoki T, Esato K (1997) Surgical stress and the development of complications in relation to polymorphonuclear leukocyte elastase (PMNE) levels. Surg Today 27: 135-139

Oka Y, Murata A, Nishijima J, Yasuda T, Hiraoka N, Ohmachi Y, Yasuda T, Kitagawa K, Toda H, Tanaka N (1994) Enhanced attachment and elastase-releasing capacity of neutrophils after surgery. Am J Surg 167: $405-411$
Orr FW, Wang HH, Lafrenie RM, Scherbarth S, Nance DM (2000) Interactions between cancer cells and the endothelium in metastasis. J Pathol 190: 310-329

Pross M, Mantke R, Kunz D, Reinheckel T, Halangk W, Lippert H, Schulz HU (2002) Reduced neutrophil sequestration in lung tissue after laparoscopic lavage in a rat peritonitis model. World J Surg 26: 49-53

Shiromizu A, Suematsu T, Yamaguchi K, Shiraishi N, Adachi Y, Kitano S (2000) Effect of laparotomy and laparoscopy on the establishment of lung metastasis in a murine model. Surgery 128: 799-805

ten Kate M, Hofland LJ, van Grevenstein WM, van Koetsveld PV, Jeekel J, van Eijck $\mathrm{CH}$ (2004) Influence of proinflammatory cytokines on the adhesion of human colon carcinoma cells to lung microvascular endothelium. Int J Cancer 112: 943 - 950

Terada LS, Hybertson BM, Connelly KG, Weill D, Piermattei D, Repine JE (1997) XO increases neutrophil adherence to endothelial cells by a dual ICAM-1 and P-selectin-mediated mechanism. J Appl Physiol 82: 866-873

Ure BM, Niewold TA, Bax NM, Ham M, Zee DC, Essen GJ (2002) Peritoneal, systemic, and distant organ inflammatory responses are reduced by a laparoscopic approach and carbon dioxide $v s$ air. Surg Endosc 16: 836-842

van den Tol PM, van Rossen EE, van Eijck CH, Bonthuis F, Marquet RL, Jeekel H (1998) Reduction of peritoneal trauma by using nonsurgical gauze leads to less implantation metastasis of spilled tumor cells. Ann Surg 227: $242-248$

van Rossen ME, Sluiter W, Bonthuis F, Jeekel H, Marquet RL, van Eijck CH (2000) Scavenging of reactive oxygen species leads to diminished peritoneal tumor recurrence. Cancer Res 60: $5625-5629$

van Rossen ME, Stoop MP, Hofland LJ, van Koetsveld PM, Bonthuis F, Jeekel J, Marquet RL, van Eijck CH (1999) Red blood cells inhibit tumour cell adhesion to the peritoneum. Br J Surg 86: $509-513$

Varga G, Gal I, Roth E, Lantos J, Jaberansari MT (1997) Inflammatory mediators and surgical trauma regarding laparoscopic access: neutrophil function. Acta Chir Hung 36: 368-369

Wayne JD, Abdalla EK, Wolff RA, Crane CH, Pisters PW, Evans DB (2002) Localized adenocarcinoma of the pancreas: the rationale for preoperative chemoradiation. Oncologist 7: $34-45$

Weese JL, Ottery FD, Emoto SE (1986) Do operations facilitate tumor growth? An experimental model in rats. Surgery 100: 273-277

Weiss L (1985) Principles of Metastasis. New York: Academic Press Inc

Yokota K, Nishihira T, Shineha R, Sayama J, Nitta Y, Kimura M, Mori S (1995) Association between elevated plasma granulocyte colony-stimulating factor and the degree of surgical stress in patients undergoing gastrointestinal surgery. Surg Today 25: 579-584 